\title{
EFFECTS OF CHROMIUM ON PROTEIN AND CARBOHYDRATE LEVELS IN THE MANTLE OF FRESHWATER MUSSEL Anodonta woodiana (Lea, 1834)
}

Andhika Puspito Nugroho, Raditia Nugraha, and Nova Prasetyaningrum

\section{INTRODUCTION}

Chromium is one of the technical importance metals found in the aquatic environment at increasing concentrations, resulting from metallurgic, refractory, chemical, and tannery industries (Satyaparameshwar et al., 2006). The metal is known to be essential for all animals such as maintenance of normal glucose tolerance (Chassard-Bouchaud et al., 1989). It also involves in metabolisms of lipids, proteins, nucleic acids, and mineral substances (Pechova \& Pavlata 2007). At elevated concentrations, chromium is toxic to mussels, resulting in changes of mRNA expression, immunomodulation, DNA stability, and stress response pathways (Franzellitti et al., 2012). Swan mussels (Anodonta woodiana) living at the interface of the free-flowing water and the sediment phase of many lotic freshwater ecosystems are known to accumulate metals in their body. Mussels require carbohydrates as main energy source for their metabolic processes (Honkoop et al., 1999). Proteins are also required by mussels for catalyzing biochemical reactions, transport and storage of molecules in and out, or within cells, and have structural and mechanical functions (Albert et al., 1994). Proteins and carbohydrates are also important components in the shell formation (Marie et al., 2007; Marin \& Luquet 2004). Mantle secretes proteins and carbohydrates into extra pallial fluid, which is directly adjacent to the shell. The objective of this research was to study the effects of $\mathrm{Cr}$ on the protein and carbohydrate levels in the mantle of $A$. woodiana.

\section{MATERIALS AND METHODS}

In this study, 42 mussels were divided into 2 groups, each group consisting of 21 mussels. The mussels were placed in an aquarium $(100 \mathrm{~L})$ containing $50 \mathrm{~L}$ of artificial pond water (APW). The first group was the control, the second one being treated by $\mathrm{K}_{2} \mathrm{Cr}_{2} \mathrm{O}_{7}$ at 0.5 $\mu \mathrm{mol} \mathrm{L}^{-1}$. For analysis, three mussels each were taken randomly from every group at days 0 , $6,12,18,24,30$, and 36. Hemolymph and extrapallial fluid are withdrawn from posterior adductor using 5-mL syringes with $0.55 \times 25 \mathrm{~mm}$ needles, transferred into 2-mL microtubes, and kept at $-80^{\circ} \mathrm{C}$. The mussels are dissected on ice to obtain mantle. The tissue was washed twice with bidistilled water and dried using filter paper. Aliquot of about $5-10 \mathrm{mg}$ of the tissue fraction was placed in 2-mL microtubes of known weight and frozen to $-80^{\circ} \mathrm{C}$. Protein and carbohydrate contents were analyzed by the Bradford and phenol-sulfuric acid methods, respectively. 


\section{RESULTS AND DISCUSSION}

Exposure of $A$. woodiana to chromium at $50 \mu \mathrm{mol} \mathrm{L}^{-1}$ induced increases of soluble protein levels in the mantle. The maximum level was reached at day 12, about 1.3-fold above control value (Figure 1). The increases indicated that chromium at low concentration was an essential element, involving in protein synthesis (Lacy, 2003). Satyaparameshwar et al. (2006) reported that exposure of Lamellidens marginalis to chromium at $80 \mu \mathrm{mol} \mathrm{\textrm {L } ^ { - 1 }}$ for $72 \mathrm{hr}$ resulted in decreases of protein in the mantle by about $20 \%$. Upon depuration, soluble protein level returned fully back to control value within the first 6 days. At day 36 , protein contents showed a decrease of $20 \%$ compared to control. For carbohydrates, the levels decreased strongly within the first 12 days, i.e. by about $60 \%$ (Figure 2). The decreases showed that carbohydrates are a sensitive toxicological endpoint. Vijayavel et al. (2007) demonstrated that chromium exposure reduced carbohydrate levels in the green mussel Perna viridis. Upon depuration, soluble carbohydrate levels increased but not fully back to control within 12 days. The level declined strongly at end of depuration. Decreased carbohydrate levels suggest that the mussels may not have sufficient energy and essential nutrients for normal reproduction, growth, and development. At the same time, carbohydrates and proteins are important components of the organic matrix which control $\mathrm{CaCO}_{3}$ polymorphism, size, and shape of the crystallites (Marin \& Luquet 2004).

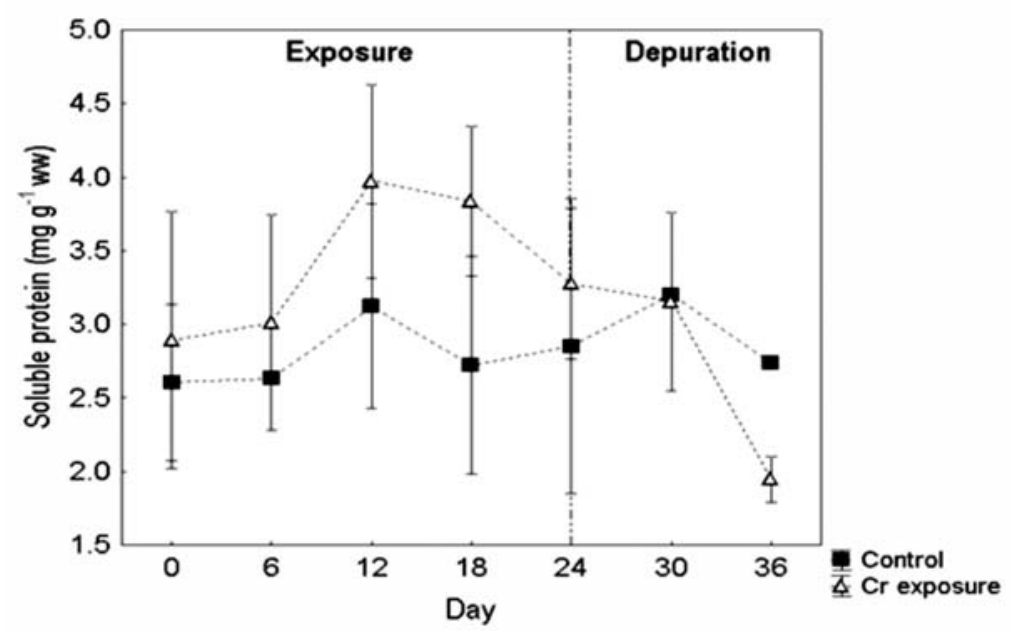

Figure 1. Contents of soluble proteins in the mantle of $A$. woodiana.

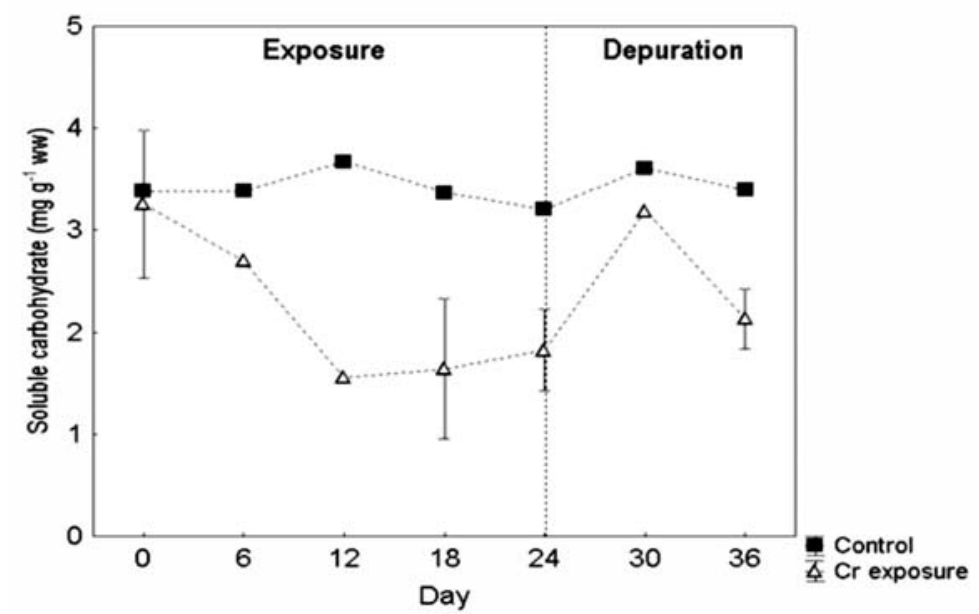

Figure 2. Contents of soluble carbohydrates in the mantle of $A$. woodiana. 


\section{REFERENCES}

Albert, B., D. Bray, J. Lewis, M. Raff, K. Robert, and J.D. Watson. 1994. Molecular biology of the cell. $3^{\text {rd }}$ edition. New York: Garland Publishing.

Chassard-Bouchaud, C., J.F. Boutin, P. Hallegot, and P. Galle. 1989. Chromium uptake, distribution and loss in the mussel Mytilus edulis: a structural, ultrastructural and microanalytical study. Diseases of Aquatic Organisms, vol. 7:117-136.

Franzellitti, S., A. Viarengo, E. Dinelli, and E. Fabbri. 2012. Molecular and cellular effects induced by hexavalent chromium in Mediterranean mussels. Aquatic Toxicology, vol. 124-125:125-132.

Honkoop, P.J.C., J.V. der Meer, J.J. Beukema, and D. Kwast. 1999. Reproductive investment in the intertidal bivalve Macoma balthica. Journal of Sea Research 41:203-212.

Lacy, S. 2003. Hyperactivity ADHD: New solution. Bloomington: Authorhouse.

Marie, B., G. Luquet, J.P.D. Barros, N. Guichard, S. Morel, G. Alcaraz, L. Bollache, and F. Marin. 2007. The shell matrix of the freshwater mussel Unio pictorum (Paleoheterodonta, Unionoida): Involvement of acidic polysaccharides from glycoproteins in nacre mineralization. FEBS Journalvol. 274:2933-2945.

Marin, F., and Luquet, G. 2004. Molluscan shell proteins. Comptes Rendus Palevol 3:469492.

Pechova, A., and L. Pavlata. 2007. Chromium as an essential nutrient: a review. Veterinarni medicana, vol. 52:1-18.

Satyaparameshwar, K., T.R. Reddy, and N.V. Kumar. 2006. Effect of chromium on protein metabolism of fresh water mussel, Lamellidens marginalis. Journal of Environmental Biology, vol. 27:401-403.

Vijayavel, K., S. Gopalakrishnan, A. Chezhian, and M.P. Balasubramanian. 2007. Biochemical constituents and bioaccumulation as biomarkers in the green mussel Perna viridis with reference to silver and chromium toxicity. Toxicological and Environmental Chemistry vol. 89:353-361. 